\title{
Consequences of organizational commitment in abolished company sports team - A case study in Japan-
}

\author{
Yuki HONDA a ${ }^{\text {, Yasuyuki HOCHI }}{ }^{\mathrm{a}}$, Motoki MIZUNO ${ }^{\mathrm{a}}$ \\ a Juntendo University Graduate School of Health and Sports Science
}

\begin{abstract}
The purpose of this study was to show that how the abolishment of company sports team influenced the organizational commitment in employees. In this study, Three-Component Model of Organizational Commitment (Meyer and Allen, 1997) was tested with 16 employees (10 males, 6 females) of T Company in NAGANO prefecture. The average age of the participants was 44,50 years $(S D= \pm 0.85)$. And from 16 employees, 3 male employees were measured on organizational commitment with interview test. According to the analysis, the relation between organizational commitment in employees and the abolishment of company sports team was not positive significant correlation. Furthermore, results of interview test did not show the relation between organizational commitment in employees and the abolishment of company sports team. However, results of interview test showed the relation with organizational commitment of players in T Company sports team. Consequently, the goal to possess a sports team in T Company was not to boost organizational commitment in employees. In addition, it is necessary to reconsider the correlation among employees engaged in T Company in the future.
\end{abstract}

Keywords: bubble economy collapse, interview test, abolishment

\section{Introduction}

The number of company sports team is decreasing since bubble economy collapse in Japan (Table1). So far company sports teams have been quite successful before bubble economy collapse. According to Niwa S. and Harada M (2010), holding sport teams in own company motivate employees. Hence, it is not very useful from the economic perspective to hold sport teams in company (Niwa S. and Harada M. 2010). However, little is known about the influence of abolishment of company sport teams among employees. Therefore, the purpose of this study was to show that how the abolishment of company sports team influenced the organizational commitment in employees.
Table1

Abolished Company Sports Team in Japan

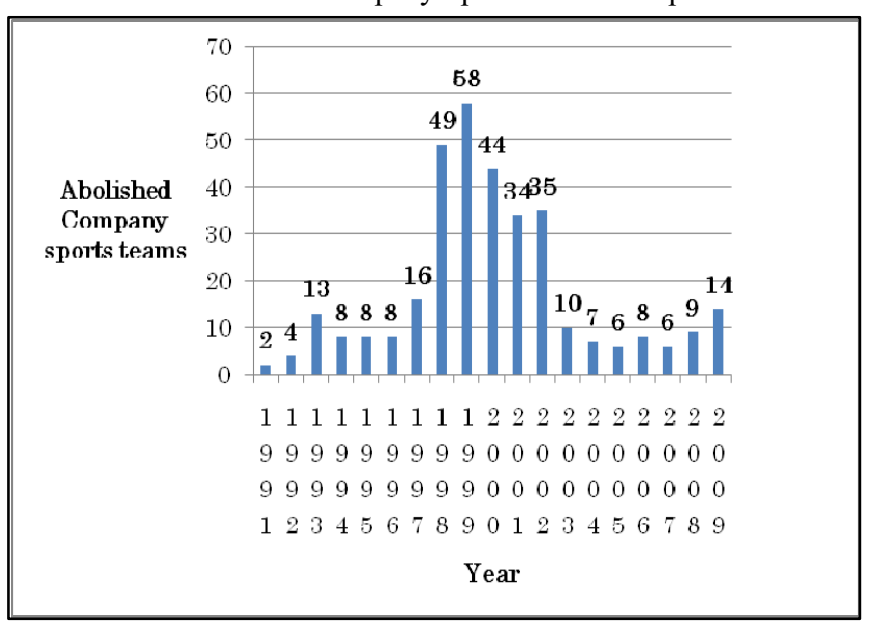




\section{Practice innovation (methods)}

(1) Three-Component Model of Organizational Commitment (Meyer and Allen, 1997) was tested with 16 employees (10 males, 6 females) of T Company in NAGANO prefecture in questionnaire survey. The average age of the participants was 44, 50 years $(\mathrm{SD}= \pm 0.85)$. And (2) Interview survey was carried out targeting to a 3 male employees of T Company in NAGANO prefecture on November in 2010.

\section{Findings and Discussion}

According to the analysis, the relation between organizational commitment in employees and the abolishment of company sports team was not positive significant correlation. Furthermore, results of interview test did not show the relation between organizational commitment in employees and the abolishment of company sports team. However, results of interview test showed the relation with organizational commitment of players in $\mathrm{T}$ Company sports team. Consequently, the goal to possess a sports team in $\mathrm{T}$ Company was not to boost organizational commitment in employees (Table2). In addition, it is necessary to reconsider the correlation among employees engaged in T Company in the future.

Table2

Interview Comments

\begin{tabular}{|c|l|}
\hline Interviewee & \multicolumn{1}{|c|}{ Mental change for the T company } \\
\hline $\begin{array}{c}\text { A } \\
\text { male }\end{array}$ & $\begin{array}{l}\text { I think that players in T company sports } \\
\text { team want to contribute as much as possi- } \\
\text { ble to the company in the environment of } \\
\text { being allowed to give a work while play- } \\
\text { ing baseball. But, I don't think that em- } \\
\text { ployees in T company want to contribute. }\end{array}$ \\
\hline $\begin{array}{c}\text { B } \\
\text { male }\end{array}$ & $\begin{array}{l}\text { I think that decrease of interchange } \\
\text { between employees and employees in T } \\
\text { company through the supporting influ- } \\
\text { ence for motivation of employees in T } \\
\text { company. }\end{array}$ \\
$\begin{array}{c}\text { C } \\
\text { (age=30) } \\
\text { male }\end{array}$ & $\begin{array}{l}\text { Aa...I think that purpose of T com- } \\
\text { pany's employees was not supporting for } \\
\text { players in T company sports team. So, I } \\
\text { think that purpose of T company's em- } \\
\text { ployees was working for themself. }\end{array}$ \\
\hline
\end{tabular}

\section{References}

[1] Allen, N.J., \& Meyer, J.P. "The measurement and antecedents of affective, continuance, and normative commitment to the organization," Journal of Occupational Psychology, 63, 1-18. (1990).

[2] Dunham, R. B., Grube, J. A., \& Casteneda, M. B. Organizational commitment: The utility of integrative definition. Journal of Applied Psychology, 79, 370-380. (1994).

[3] Mathieu, J. E., \& Zajac, D. M.A review and metaanalysis of the antecedents, correlates, and consequences of organizational commitment. Journal of Applied Psychology, 108, 171-194. (1990).

[4] Meyer, J. P., \& Allen, N. J. testing the "side-bet theory" of organizational commitment: Some methodological consideration. Journal of Applied Psychology, 69, 372-378. (1984).

[5] Meyer, J. P., Allen, N. J., \& Smith, C. A. "Commitment to organizations and occupations: Extension and test of a three-component conceptualization," Journal of Applied Psychology, 78, pp, 538551. (1993).

[6] Meyer, J. P., \& Allen, N. J. "Commitment in the workplace: "Theory, research, and application. Thousand, Osks, CA: Sage.(1997).

[7] Mowday, R. T., Porter, L. M., \& Steers, R. M. Employee-Organization Linkages: The Psychology of Commitment, Absenteeism, and Turnover. New York: Academic Press. (1982).

[8] Niwa S, Harada M: The study of corporate owning their sport team influences employee's commitment to an organization, Annual Bulletin of Institute of Sports Sciences Waseda University, pp.158-204. (2010).

[9] O’Reilly, C. A., \& Chatman, J. Organizational commitment and psychological attachment: The effects of compliance, identification, and internalization on prosocial behavior. Journal of Applied Psychology, 71, pp.492-499.(1986).

[10] Porter, L. W., Steers, R. M., Mowday, R. T., \& Boulian, P. V. Organizational commitment, job satisfaction, and turnover among psychiatric technicians. Journal of Applied Psychology, 59, 603609. (1974)

[11]Sato M, Shimizu Y: Environmental changes caused by corporate merger and psychological adjustment of employees, Annual Bulletin of Institute of Psychological Studies. Showa Women's university. pp.43-53. (2007). 